\title{
QUIJADA, Mónica (ed.). De los cacicazgos a la ciudadanía. Sistemas políticos en la frontera, Río de la Plata, siglos XVIII- XX, Gebr. Mann Verlag, Berlín, 2011
}

\section{Gabriela Dalla-Corte Caballero*}

En esta obra editada por Mónica Quijada encontramos cuatro excelentes trabajos sobre la zona fronteriza rioplatense entre los siglos XVIII y XX. En primer lugar, Lidia Nacuzzi aborda los cacicazgos del siglo XVIII en el territorio fronterizo de Pampa-Patagonia y en el espacio definido como "Chaco" que en los últimos años afortunadamente ha gozado de un creciente interés académico. El segundo trabajo corresponde a Ingrid de Jong y se centra en las alianzas políticas indígenas de la Pampa y de la Patagonia durante la segunda mitad del siglo XIX, es decir en el periodo de la organización nacional argentina. El tercer trabajo incluido en esta obra pertenece a Mónica Quijada y trata sobre los “indios amigos” de Buenos Aires en su proceso de construcción de la “ciudadanía cívica” en la zona de frontera desde 1820 a 1880, es decir, hasta el triunfo del Estado Nacional argentino. Finalmente, el cuarto artículo es obra de María Argeri y trata la desestructuración de los cacicazgos de Pampa y Patagonia entre 1870 y el declive del gobierno de Juan Domingo Perón en el año 1955. Sobre esta base descriptiva, el primer señalamiento de esta reseña tiene que ver con el interés que produce la lectura de un libro que no pretende darnos historia argentina, sino historia de los indios en las zonas de frontera en momentos puntuales y cambiantes. Como señala la propia responsable de la obra, es resultado de dos antropólogas y de dos historiadoras reunidas en torno a la Red Temática sobre la construcción del pensamiento y método antropológicos en Europa y América Latina que es dirigida por Quijada y Nacuzzi desde el año 2003.

\footnotetext{
* Doutora em História da América e também em Antropologia Social e Cultural. Professora da Universidade de Barcelona - Espanha. E-mail: dallacorte@ub.edu
} 
Las autoras se centran en el cruzamiento y el mestizaje producido en la frontera indígena de la Provincia de Buenos Aires y de los Territorios Nacionales de la zona patagónica que, mucho antes de que la mirada argentina se dirigiese al Territorio Nacional del Gran Chaco, recibieron un gran interés del Estado Argentino. El rosarino Estanislao Severo Zeballos diseñó por entonces el proyecto de ocupación de las “quince mil leguas” que dio lugar en pleno año 1878 a la publicación del libro La conquista de quince mil leguas tal como aparece en la histórica obra publicada en la capital argentina. Esta frase guió recientemente a la publicación del libro Scribere est Agere, Estanislao Zeballos en la vorágine de la modernidad Argentina en manos de Sandra Fernández y Fernando Navarro (La Quinta Pata, Rosario, 2011), con el afán de describir la ocupación territorial y el sometimiento de los indios de frontera gracias al inteligente “ojo ocular” del personaje más importante que tuvo la Argentina en esas décadas, Zeballos.

El eje de los diversos estudios del libro que reseñamos se centra en el diseño de los sistemas políticos en la frontera rioplatense y la transformación de los Cacicazgos a la Ciudadanía producida entre los siglos XVIII y XX, es decir, durante la Monarquía y también durante el periodo Republicano. Más allá de las diferencias antes señaladas, interesa enunciar los temas centrales que otorgan interés a la obra. Me refiero al proceso de avance de los "blancos” (que en la documentación de la zona chaqueña controlada por la orden franciscana suelen aparecer como “criollos” y “extranjeros”) en las tierras de los indígenas que, como indica la propia Quijada, no tuvieron consciencia sobre el territorio sino sólo percepción ante el "espacio político-social”.

Uno de los ejes más importantes de esta obra es la utilización del término "Cacicazgo" que las autoras vinculan a la antigua "República de Indios” en la época hispánica colonial, y que también aplican en las zonas de frontera signadas por los “indios bravos" desde el proceso de independencia y durante la construcción de la nación argentina. Este concepto es verdaderamente central y por ello considero que la obra coordinada por Mónica Quijada otorga creatividad a la investigación histórica si las dirigimos a comprender el vínculo de los aborígenes con los inmigrantes que se expandieron en el Río de la Plata. Lidia R. Nacuzzi señala la presencia indígena y su relación con los misioneros, que primero fueron jesuitas y posteriormente básicamente franciscanos, así como con los funcionarios del que muy pronto, a inicios del siglo XIX, sería la provincia santafesina en la zona de frontera del Gran Chaco. Llamativamente en este trabajo se diferencia a los españoles de los europeos que ampliaron el control de tierras en el siglo XVIII cuando poco después, lograda la independencia, la condición de español fue identificada como europea. 
Ingrid de Jong sale de la etapa hispánica y se centra en la organización nacional y en el papel del comercio y de la entrega de raciones a los indígenas, así como la proliferación de tratados de paz para asegurar el poderío del gobierno argentino. En un caso concreto, el de la Confederación Indígena de Calfucurá, la autora observa el espíritu pacífico de los aborígenes en Pampa y Patagonia. En una línea similar se suma la propia Quijada que nos ofrece nueva información sobre los fortines que el gobierno argentino, y también los gobiernos provinciales, crearon en lo que históricamente se ha denominado como "desierto" argentino de la zona sur de Buenos Aires. Hay diversos temas tratados por la autora como el uso de los soldados del ejército que fueron contratados para la ocupación de tierras hasta entonces inexploradas; la donación de tierras que también se dio en otras provincias del área pampeana como fue la propia Provincia de Santa Fe; y especialmente la ampliación del espacio en el periodo histórico que va de Juan Manuel de Rosas a Bartolomé Mitre. Resulta significativo que el artículo de Quijada incluya las fotografías de los indígenas pampeanos que se conservan en el Archivo Nacional de la Nación (AGN) de Argentina, y que a mi juicio tienen diferencias notables con las imágenes que conservan los misioneros franciscanos en la zona chaqueña de la Diócesis de Santa Fe, en concreto en el Convento San Carlos Borromeo de San Lorenzo, para la misma época.

Finalmente, María Argerich cierra el libro con los conceptos guerra y paz en el espacio pampeano y patagónico en el inicio de la República Argentina (1870 aproximadamente) y el fin del gobierno del militar Juan Domingo Perón en pleno año 1955. La autora nos recuerda el uso del concepto “comunidades domésticas patriarcales” que no tuvo efecto en otras zonas, como por ejemplo en el propio espacio chaqueño de los aborígenes mocovíes. En este caso concreto la autora señala que la vida indígena sufrió una derrota a partir de aquella fecha, y que puede servirnos para estudiar los importantes territorios chaqueños que son los menos explorados hasta el día de hoy. Espero que este libro otorgue ideas para los futuros estudios del Gran Chaco que sigue siendo un digno territorio de los indígenas guaycurúes. Estos indígenas, también establecidos en las zonas de frontera, llegarán a tener tanta producción como la Pampa y la Patagonia que se expresa en esta obra coordinada por Mónica Quijada y titulada De los Cacicazgos a la Ciudadanía. 